University of Nebraska - Lincoln

DigitalCommons@University of Nebraska - Lincoln

UCARE Research Products

UCARE: Undergraduate Creative Activities \&

Research Experiences

Spring 4-14-2020

\title{
Phosphorus NMR and its application to metabolomics
}

\author{
Paula Evans \\ University of Nebraska - Lincoln, padowdy29@gmail.com \\ Fatema Bhinderwala \\ University of Nebraska - Lincoln \\ Robert Powers \\ University of Nebraska - Lincoln, rpowers3@unl.edu \\ Martha Morton \\ University of Nebraska - Lincoln, mmorton4@unl.edu \\ Thomas Smith \\ University of Nebraska - Lincoln, tsmith@unl.edu
}

Follow this and additional works at: https://digitalcommons.unl.edu/ucareresearch

Part of the Analytical Chemistry Commons

Evans, Paula; Bhinderwala, Fatema; Powers, Robert; Morton, Martha; and Smith, Thomas, "Phosphorus NMR and its application to metabolomics" (2020). UCARE Research Products. 193.

https://digitalcommons.unl.edu/ucareresearch/193

This Poster is brought to you for free and open access by the UCARE: Undergraduate Creative Activities \& Research Experiences at DigitalCommons@University of Nebraska - Lincoln. It has been accepted for inclusion in UCARE Research Products by an authorized administrator of DigitalCommons@University of Nebraska - Lincoln. 
